\title{
The Paradoxes in the Use of the Panopticon as a Theoretical Reference in Urban Video-surveillance Studies: A Case Study of a CCTV System of a Brazilian city
}

\author{
IAFET LEONARDI BRICALLI \\ University of Genoa, Italy
}

\begin{abstract}
This article aims at introducing the relation between the use of CCTV systems in urban spaces and social control. More specifically, its purpose is to problematize and reaffirm the use of the theoretical background of the panopticon in order to interpret such a relation. In CCTV studies, as a consequence of literal interpretations, as well as the existence of a hegemony in ethnographic studies carried out in control rooms, the theoretical use of the panopticon is then questioned. In this article, based on an ethnographic study conducted in the public spaces surveilled by a CCTV system in a Brazilian city, it can be concluded that the effects of social control through surveillance are paradoxical. The indifferent way in which citizens deal with surveillance, or even the lack of awareness of it, imposes limits to the interpretation of the system as a tool of social control. Thus, the use of the panopticon becomes problematic. However, this research has shown how the presence of cameras in public spaces makes it conducive for a state of control in the form of a network whose project would be a mythical and homogeneous ordering of the spaces. The importance of the interpretation of Jeremy Bentham's panopticon by Michel Foucault is then reaffirmed, that is, panopticism as a trend of normalization and moralization of the public spaces.
\end{abstract}

Keywords: Panopticon - Social Control - CCTV - Public Spaces - Vila Velha

\section{INTRODUCTION}

The use of closed circuit television cameras (CCTV) systems has become widespread in the public spaces of cities since the 1990s, experienced a rise in the 2000s, and is now a standard response of public administrations in law enforcement. It is much more of a political response than a solution or even an alternative in the field of public security. In the absence of social and welfare concerns that dominated the field of law enforcement until the 1970s, the use of cameras in public spaces is part of the neoliberal crime management strategy. ${ }^{1}$ In this case, public administrations need to show something is being done in the

\footnotetext{
${ }^{1}$ David Garland, The Culture of Control: crime and social order in contemporary society (2001), 1.
} 
name of security. Besides that, the use of CCTV systems has become quite appealing considering the aspects of technology and modernity featured by them. ${ }^{2}$

In addition to the approach of the CCTV system as a security tool, this text is based on the premise that the use of cameras in public spaces has the effect of increasing control over citizens and their spaces. More specifically, this article proposes to reaffirm the importance of the theoretical reference of the panopticon of Jeremy Bentham ${ }^{3}$ and mainly its reinterpretation by Michel Foucault ${ }^{4}$ for the study on the exercise of power in its relation with the operation of CCTV systems in public spaces.

In urban surveillance studies on the use of CCTV systems in public spaces, a certain criticism can be noticed regarding the use of the panopticon as a theoretical reference that is, in our view, only partially true for two main reasons: first, from a literal interpretation, it is believed the panopticon is only an instrument of correction of individuals in enclosed spaces. ${ }^{5}$ We believe, however, that the literal understanding of the panopticon can lead to insufficient conclusions. In our view, more important than the panopticon is its interpretation by Michel Foucault, that is, panopticism. ${ }^{6}$ Here the panopticon is understood as a modern metaphor of surveillance that acts through a network, which stems from multiplying views.

Secondly, such studies corroborate with the results obtained from micro-sociological research in the control rooms where the cameras are operated. ${ }^{7}$ The studies aim at offering critique of technological determinism by emphasizing the importance of human labor "behind" the cameras in order to demystify both the use by governments of CCTV systems as a tool to fight crime and its interpretation as an instrument of control. This is what Laurent Mucchielli calls respectively the gold and the black legend of video surveillance, that is, the technological determinism that dominates those who are for and against CCTV

\footnotetext{
2 In the name of urban crime and security, therefore, CCTV systems are used. But there are, of course, publicprivate partnerships that illustrate corporate interests in the implementation of the system, both in the creation of revitalized urban spaces for consumption, where cameras are an essential part of the project of revitalization, as well as in the trade of the devices which make up the system, produced by specialized companies. See, respectively, Roy Coleman and Joe Sim, “'You'll never walk alone': CCTV surveillance, order and neoliberal rule in Liverpool city centre", British Journal of Sociology 51:4 (2002), 624, for the case of Liverpool, in the UK, and Laurent Mucchielli, Vous êtes Filmés: enquete sur le bluff de la vidéosurveillance (2018), 57.

3 Jeremy Bentham, "Panopticon or the Inspection-House" [1791], in The Panopticon writings ed. Miran Bozovic (1995), 32.

${ }^{4}$ Michel Foucault, Discipline and Punish: the birth of the prison [1975] (1977), 195.

5 See Clive Norris and Gary Armstrong, The Maximum Surveillance Society: The Rise of CCTV (1999), 92-93 and Hille Koskela, 'The gaze without eyes': video-surveillance and the changing nature of urban space, Progress in Human Geography 24:2 (2000), 252.

${ }^{6}$ Michel Foucault, Discipline and Punish, 195.

7 See Gavin J. D. Smith, Behind the Screens: Examining Constructions of Deviance and Informal Practices among CCTV Control Room Operators in the UK, Surveillance \& Society 2:2/3 (2004); Francesca Menichelli, "WHAT'S CRIME GOT TO DO WITH IT? CCTV, urban security and governing elites" (PhD diss.,Università degli studi Milano Bicocca (2012); Rodrigo José Firmino and Elisa Trevisan. "Eyes of glass: Watching the watchers in the monitoring public spaces in Curitiba, Brazil," Surveillance and Society 1:10 (2012); Iafet Leonardi Bricalli and Cláudio Luiz Zanotelli, “A fragilização dos espaços públicos a partir da utilização de câmeras de vigilância na cidade de Vila Velha (ES)," Revista Geo UERJ 29 (July 2016).
} 
systems. ${ }^{8}$ We believe, nonetheless, that the criticism of technological determinism and, therefore, the demonstration of the limits of CCTV systems for surveillance, while fundamental, may lead to an exaggerated relativization of the approach of these systems from the point of view of social control, since the correctional effects of the state upon surveilled sites and passersby are virtually nonexistent. Research "in front" of the cameras, made in the public spaces monitored by them and in order to verify the way people deal with them, may signal a different path.

In order to reaffirm the importance of social control in CCTV studies based on panopticism, we will present the empirical results of a study on the effects of video surveillance in the public spaces in a southeastern Brazilian city, Vila Velha. As a complement to the micro-sociological study "behind" the cameras (in the control room where the cameras are operated), we carried out a study "in the front" of the cameras (in some public spaces monitored by them). Such results will be prioritized in this text so as to answer the question we have proposed.

\section{THE PANOPTICON AND THE MODERN ALL-KNOWING UTOPIA}

On at least one of its facets, modernity can be read as a project of order. A "better" world is sought, subject to the exclusive principles of reason, in which the human being and the irrationality that accompanied it needed to be controlled in order to achieve that goal. Progress was nothing more than the utopia of an exclusively rational, perfect world, where science and technology are the instruments to pursue this perfection.

The modern project could not admit anything that was not necessary. Anything that would be useless or undesirable, that would cause unhappiness or discomfort, would be understood as an obstacle in search of this project of control over the human condition. As Zygmunt Bauman argues:

The conviction that such a feat is plausible, feasible, in sight and within human reach, as well as the irresistible urge to act on that conviction, was and remains the defining attribute of modernity. ${ }^{9}$

The project of order of modernity brings with it the all-knowing ideal, of seeing everything. It was not by chance that such project came to be known as the Enlightenment, the "Age of Lights", in opposition to the alleged obscurantism that ruled in the medieval period. In the Enlightenment, transparency had to be absolute.

According to Foucault, the modern project of absolute transparency is a type of power exercised by the gaze, which materializes in closed institutions such as schools, hospitals, military facilities, factories and their respective surveillance models, but whose archetypal model is the prison-like project of surveillance proposed by Jeremy Bentham, called the panopticon. ${ }^{10}$ The principle was the following:

\footnotetext{
${ }^{8}$ Laurent Mucchielli, Vous êtes Filmés, 34-42.

${ }^{9}$ Zygmunt Bauman and David Lyon, Liquid Surveillance (2013), 71.

10 Bentham, "Panopticon or the Inspection-House", 32.
} 
A perimeter building in the form of a ring. At the centre of this, a tower, pierced by large windows opening onto the inner face of the ring. The outer building is divided into cells each of which traverses the whole thickness of the building. These cells have two windows, one opening onto the inside, facing the windows of the central tower, the other, outer one allowing daylight to pass through the whole cell. All that is then needed is to put an overseer in the tower and place in each of the cells a lunatic, a patient, a convict, a worker or a schoolboy. The back lighting enables one to pick out from the central tower the little captive silhouettes in the ring of cells. In short, the principle of the dungeon is reversed; daylight and the overseer's gaze capture the inmate more effectively than darkness, which afforded after all a sort of protection. ${ }^{11}$

In the surveillance model described above, the most important aspect is to realize the consequence of this type of surveillance: if the guard of the central tower has an uninterrupted view of the cells, the opposite is not true: from the cells it is impossible to see the presence or not of the guard in the central tower. What does it mean? It means that the mere presence of the tower, regardless if the guard is present or not, is the instrument of control. Being unaware of the presence of the guard in the central tower, the prisoner feels uninterruptedly watched, feeling the gaze weigh on them, which guarantees the automatic functioning of power. In the panopticon, the inmate internalizes the surveillance and becomes the instrument of self-control.

Michel Foucault uses the inscription of the panopticon in a closed institution, such as a prison, only to signal the beginning of a society marked by panopticism. The panopticon must be understood as a metaphor for a model of surveillance exercised by the gaze that permeates through the entire social body; "its functioning [...] is in fact a figure of political technology that may and must be detached from any specific use" ${ }^{\prime 12}$ The understanding of panopticism as a metaphor, in a non-concrete, non-literal fashion (an architectural model of closed social institutions) means to understand it, according to Gilles Deleuze ${ }^{13}$, as an abstract formula that is not only about seeing without being seen but also about imposing any conduct on any human multiplicity.

But panopticism is not only a project that aims at correcting the souls of the subjects, taken individually or from a collective. As the instrument of the modern design of order, panopticism must be understood from a moral point of view, which aims at normalizing, standardizing, homogenizing or, at least, making the differentiations useful within society.

In the research carried out by Michel Foucault, panopticism is the symbol of control of a type of society that he coined as disciplinary. According to Foucault, the disciplinary society is a complement to sovereign power when the state held the monopoly of exercising power, fundamentally characterized by the existence of a legal framework that defined the limits of what was prohibited and allowed. The disciplines, whose instrument is panopticism, are small mechanisms of surveillance irradiated by the social body as a

\footnotetext{
${ }^{11}$ Michel Foucault, “The eye of power” [1977], in Power/Knowledge: Selected Interviews and Other Writings 19721977, ed. Colin Gordon (1980), 147.

${ }_{12}$ Discipline and Punish, 205.

${ }^{13}$ Gilles Deleuze, Foucault [1986] (2006), 34.
} 
whole, whose purpose would be to fill the voids left by laws. If the sovereign power has failures because it is not continuous, disciplines are meant to be perfect as they are constant. ${ }^{14}$

Foucault's interpretation of panopticism is of utmost importance since, in this case, power ceases to be radiated from a single focus, as when it was understood as the exclusive monopoly of the state or the ruling classes. Panopticism is the exercise of power in the form of a network because:

One doesn't have here a power which is wholly in the hands of one person who can exercise it alone and totally over the others. It's a machine in which everyone is caught, those who exercise power just as much as those over whom it is exercised. ${ }^{15}$

Or, as Jeremy Bentham argues, "every comrade becomes an overseer."16

\section{THE INTERPRETATION OF THE PANOPTICON IN CCTV STUDIES}

Gilles Deleuze had already recognized that disciplinary societies were falling behind. ${ }^{17}$ After World War II and the development of electronic surveillance mechanisms, we were moving towards a society of control, represented by the management of people in open spaces of circulation, without the need of the confinement that marked the disciplines. ${ }^{18}$ In his work, Deleuze criticizes the disciplinary society but not the panopticon, because he considers it up-to-date even in what he calls a society of control.

In CCTV studies, the association of the panopticon with the use of cameras has been largely adopted, at least when it comes to the means of how surveilling takes place, which is, in fact, nearly identical. It is possible to draw an analogy in which the central surveillance tower is replaced by the control room and cameras; in turn, the prisoners are replaced by the citizens. As a matter of fact, as the central tower itself, cameras are the symbols of power, and there is no way of knowing what is happening in the central tower, or in other words, in the control room where the cameras are operated. Two hundred years after its invention by Jeremy Bentham, the panopticon is up-to-date in the public spaces of cities.

The major problem with the direct association of the panopticon with CCTV systems is when one thinks of their role. To Foucault, the most important effect of the panopticon

\footnotetext{
${ }^{14}$ Michel Foucault also shows the existence of a security society for managing the risks that the "liberties" of nineteenth-century liberalism promote. See Michel Foucault, Security, Population, Territory. Lectures at the Collège de France 1977-1978 (2009). In times of neoliberalism, this is a fruitful analysis for approaching CCTV systems, but which will not be done here because it would go beyond the scope of the work. For the problematic relation between modernity and the risks that accompany it, see also Ulrich Beck, Risk society: towards a new modernity (1992).

${ }^{15}$ Foucault, "The eye of power", 156.

${ }^{16}$ Ibid., 152.

${ }^{17}$ Gilles Deleuze, "Postscript on control Societies" [1990], in Negotiations (1995), 177-178.

${ }^{18}$ What Gilles Deleuze called control society can be understood as "the emergence of something that is no longer an anatomo-politics of the human body, but what I would call a "biopolitics" of the human race" Michel Foucault, Society Must Be Defended: Lectures at the Collége de France, 1975-76 (2003).
} 
was "[...] to induce in the inmate a state of conscious and permanent visibility that assures the automatic functioning of power". ${ }^{19}$ The panopticon had one goal: to correct individuals. When feeling the gaze weigh on them, the individual would tend to follow a certain conduct, while they would avoid another one. Thus, it is difficult to conceive "the automatic functioning of power" when empirical research shows that most people are not aware they are being monitored ${ }^{20}$ or when people indifferently deal with surveillance. ${ }^{21}$

Literal interpretations of the panopticon, and thus the little attention given to what Foucault calls panopticism ${ }^{22}$, also do not contribute to its use as a theoretical reference in CCTV research. In closed social institutions, such as prisons and mental health institutions, knowledge of the individual and their corresponding classification is facilitated for controlling purposes. In these cases,

persons have to be officially labeled as deviant or mad for admission, and then, through surveillance and monitoring, they can be subject to further classifications which single the persons out for the need of treatment or training to foster conformity. ${ }^{23}$

The use of cameras in public spaces reveals a very different situation because, firstly, the population is not predefined as deviant and, secondly, the identity of those under surveillance is unknown. In this case, as the result of the records from unknown individuals cannot be compared with a pre-established dossier, the correctional effect is almost nonexistent.

Finally, ethnographic research in the control room where cameras are operated tends to minimize the surveillance effect exercised through CCTV systems. Research in several contexts demonstrate that video surveillance has a set of limits ${ }^{24}$ which can be grouped into two blocks:

1) The limits of the system itself: a) since the maintenance of the system does not exist or is insufficient, many cameras and control room devices (monitors, keyboards, mice, etc.) are broken and therefore do not work; $b$ ) the projection of images of a certain location is always partial. Although many cameras have the $360^{\circ}$ rotational feature, they project images of a certain point at a time, which means there is never a complete surveillance on the spaces under monitoring.

2) Human labor: a) the operators of the system are responsible for controlling an array cameras, beyond what would be humanly possible, which limits the surveillance capacity; b) informal work practices are common in camera control rooms. As a consequence, oftentimes the cameras are not monitored because workers are surfing the Internet, reading

\footnotetext{
${ }^{19}$ Discipline and Punish, 201.

${ }^{20}$ Clive Norris and Gary Armstrong, The Maximum Surveillance Society, 92.

${ }^{21}$ Bricalli and Zanotelli, “A fragilização dos espaços públicos", 147-148.

22 Foucault, Discipline and Punish, p. 195.

${ }^{23}$ The Maximum Surveillance Society, 93.

${ }^{24}$ Smith, "Behind the screens"; Menichelli, “WHAT'S CRIME GOT TO DO WITH IT?”; Firmino and Trevisan,

"Eyes of glass"; Bricalli and Zanotelli, "A fragilização dos espaços públicos".
} 
newspapers, smoking or drinking coffee; c) considering wages and working conditions are generally unfavorable, workers informally resist the system by pretending to be working, for instance; d) at certain moments of the day, such as lunch, coffee or dinner breaks, the cameras are not monitored.

These are some cases that illustrate the surveillance limits of CCTV systems. The studies that indicate these limits are paramount to question the technological determinism associated to the systems, dismantling public safety discourses when using cameras, while questioning total control in the "Big Brother" style. However, they can lead to partial interpretations of CCTV systems, making us believe that the effects of control over the monitored spaces do not exist or are unimportant.

We present below the results of empirical research on the CCTV system carried out in the southeastern Brazilian city of Vila Velha. As a complement to the ethnographic work performed behind the cameras, we went to the streets of the city, "in front" of the cameras, to analyze the relation of the presence of the cameras with the spaces under surveillance.

\section{"THESE CAMERAS DO NOT WORK!"}

The city of Vila Velha was, in 2010, the most populous city in the state of Espírito Santo, in southeastern Brazil, with 414,586 inhabitants. It covers an area of $210.67 \mathrm{~km}^{2}$, its population density is $1,973.79$ inhabitants per $\mathrm{km}^{2}$ and its urbanization rate is of $99.5 \%$, although $35.4 \%$ of the total area of the municipality is considered to be rural . It has the third largest Gross Domestic Product (GDP) in the state of Espírito Santo, only falling behind the city of Serra and the state capital, Vitória. In 2012, its GDP was USD 3.75 billion, when the service sector was the most important in the municipality, accounting for $78.62 \%$ of the wealth produced, followed by the industry $(21.18 \%$ ) and agriculture (less than $1 \%$ ) sectors. Relatively economically rich, Vila Velha is an extremely unequal city in terms of wealth distribution (its GINI index in 2003 was of 0.48 ) and presents strong aspects of socio-spatial segregation. ${ }^{25}$

With regards to public security policy, a CCTV system began to be implemented in the city in 2009. In 2014, when our research was conducted, one hundred and sixteen cameras composed the system (the largest number among all cities in the state of Espírito Santo) and were controlled in a room located downtown in the city by professionals hired by the city hall for this specific purpose, and not by the police.

Between October and November 2014, exploratory observation research was conducted in three areas of the city of Vila Velha monitored by cameras, all of which share very contrasting socio-spatial characteristics: Praia da Costa, a residential neighborhood with the wealthiest residents in the municipality; Glória, a neighborhood which is fundamentally supported by commercial and industrial activities and has an intense flow of people, automobiles and goods; and Riviera da Barra, a deprived neighborhood in the outskirts of the city with an alarming number of socio-spatial issues. The choice, in these

25 "2010 Population Census", Brazilian Institute of Geography and Statistics (IBGE), accessed on October 17, 2018, https://ww2.ibge.gov.br/home/estatistica/populacao/censo2010. 
cases, was based initially on the observation carried out in the control room and afterwards in a field visit to the neighborhoods. On random days and times, we sought to discover the relations these spaces had with the surveillance and the cameras, making observations on the uses that were made of them and, mainly, interviewing residents, passersby and merchants.

The first important observation on the research carried out in public spaces is that in two of them, Praia da Costa and Glória, a significant majority of the approached and interviewed people were not aware of the presence of cameras in those spaces. The large flow of people and cars, besides tall buildings, made the cameras a minor detail in the landscape, so they generally passed unnoticed. It was only in Riviera da Barra, an exclusively residential neighborhood, where the flow of people is considerably smaller compared to the other two areas, where the respondents were aware of the presence of the cameras, which could easily be seen in the only square of the place.

Secondly, it is also worth highlighting that, in all three neighborhoods, even those interviewed who were aware of the presence of cameras dealt with surveillance indifferently. They would not consider the possibility that cameras of a CCTV system could represent a device of control over their lives. They would live their lives and walk around the spaces as if the cameras did not exist.

It is clear that if people in public spaces in general are not aware they are being watched, the interpretation of surveillance based on the panopticon becomes limited. The induction of self-control that characterizes the panopticon depends on awareness in relation to surveillance. If people do not know they are being watched, it is not possible to imagine that their actions will be influenced by the mere presence of cameras.

Likewise, the indifferent manner in which people developed a relation with cameras was verified by them not abiding to the uses of public spaces. Thus, while the research was conducted, drug dealing and their use as well as informal commercial activities, all of which were theoretically prohibited, happened to be caught by the cameras. Respondents also reported the occurrence of various crimes in those spaces, from theft and robbery against the people and merchants, to even a murder committed in Praia da Costa. It was therefore verified that the presence of the cameras was not enough to guarantee the presumed order of the public spaces, which also led us to question the use of the panopticon as a theoretical reference.

Nevertheless, what most impressed us during the interviews were the constant claims that the cameras did not work, as the following interview excerpts show:

These cameras just don't work. There's already been four break-ins here in the restaurant, there are constant robberies, mostly money stolen from people who are leaving the banks. There is no security whatsoever. In the beginning the cameras were working well. I even got a ticket [for illegal parking] here because of the monitoring, at least the guard said he saw that through the camera (Interview with M., restaurant owner in the neighborhood of Glória, November 06, 2014).

We have already been victims of robberies, kidnapping and the camera has never helped us. There was a shooting here one of these days. Nowadays nobody cares. Criminals 
just don't care about camera. They don't feel discouraged. If these cameras made any sense, for example, they wouldn't park irregularly like people do in front of the banks (Interview with R., taxi driver from the Gloria neighborhood, October 15, 2014).

That's what they say, they don't work. But a guy came over one of these days and said it's working. We never know, right?! But I think it doesn't really work, from time to time there are robberies. They rob people right in that street over there [pointed to a street near the square]. There was this day a woman showed up here crying saying she'd just been robbed, they'd taken her phone. That street there is very dangerous (Interview with S., cyber café owner near the square in Riviera da Barra, October 28, 2014).

I've ran a bar for fourteen years. I was robbed once and there have been six more breakins. Only this year, between April and May, there's been three break-ins, and I'd had enough so I shut it down. There was a drugstore over there [pointing to a store] that had an ATM and it was robbed too. So that's why I think this camera's not working, Actually, I think it has never worked. Robberies keep on happening and the camera never catches anything, it doesn't track anybody down, it doesn't really discourage anybody. (Interview with M., resident and former owner of a commercial establishment around the square of Riviera da Barra, October 29, 2014).

It is clear the interviewees had no way of knowing whether the cameras actually worked or not. The phrase "do not work" should not be read literally. It means that the cameras did not meet what the interviewees expected of them. The excerpts from selected interviews indicate that from the interviewees' point of view the cameras did not work, because crimes keep on happening regularly in the spaces surveilled by cameras. Being political propaganda as a crime-fighting tool, the CCTV system has no credibility among the population, since the general perception is that nothing has changed with the implementation of the system. Robberies, thefts, and even murders happen "in front" of the cameras, which do not catch them, let alone prevent crimes.

The perception of the population should not surprise anyone who knows what happens "behind" the cameras. The limitations posed on the work of surveillance are countless: $35 \%$ of the cameras do not work, some of the control room equipment is broken, in some moments of the day the cameras are not in operation; the operators informally resist the system (they only pretend to be to working, for example); communication with the police, even though possible, is rarely used, etc. ${ }^{26}$ With all these limitations, the result could not be otherwise: the prevention and registration of images of crimes is virtually impossible.

It was interesting to observe that the interviewees, though they did not have the means to become aware of it, speculated about what was happening in the control room and were often right. Even if the following statements are not accurate as to what goes on in the control room, the general context is correct:

\footnotetext{
${ }^{26}$ Iafet Leonardi Bricalli, "O paradoxo da cidade monitorada: vigilância limitada e espaços públicos fragilizados a partir do estudo do sistema de câmeras do município de Vila Velha-ES" (Master's diss., Federal University of Espírito Santo, 2015), 55.
} 
Since they' re not really able to monitor this place, there should be a team patrolling each region. It really shouldn't be about detaining one single person and letting them go so they control a huge municipality like this one. They should take turns in 12-hour shifts. I don't know how these things work. To me, they had to choose a neighborhood and monitor that, another neighborhood, another monitor, and so on. By doing that it'd be much easier to report to the police central station what is happening in each place. Because the cameras are not only located here in the square, there are cameras throughout the city, so there are way too many cameras for a person to control. (Interview with G., supermarket owner in the vicinity of the square of Riviera da Barra, October 30, 2014).

At first, yes, even those who were opposed to the system, people who didn't want the system to be installed, felt discouraged, like thugs, vandals, malicious people; these people felt discouraged right away because they didn't know the system and how it worked. Then, of course, it'd worry them, but it would make people feel comfortable by knowing the system is there, you know. But then, little by little, I found out the system only worked 'til 5 p.m., that it's in collaboration with the Civil Defense Department, that they're actually conducting surveillance from the city hall. It's 24/7 monitoring only in theory because if you call them after 5 p.m. no one will answer. So after $5 \mathrm{p} . \mathrm{m}$. they don't look at anything and it's after that time, at night, that people do something, so once they learned that, nowadays it doesn't really discourage anyone (Interview with A., president of the Association of Residents of Riviera da Barra, October 17, 2014).

It sometimes works when it doesn't need to work. You know, speaking as a resident, me in my neighborhood and you in yours. You see the crime rate, regardless of the degree, mostly happens at night or dawn. During the day it works perfectly, they say "this place is monitored 24/7". How about during the nighttime? It doesn't work 24/7. I think this system should be directly linked to the military police or the civil police and not be the city hall's responsibility to call CIODES27. I think it should be directly linked to the police, because the police are the ones who are going take action, not the city hall [...] If you stick around here, eventually you'll hear "you are in a 24/7 monitored area". Then at night, as I close the shop, you hear nothing. So this is proving that at 5 p.m. you're calling it a day, and so is the camera . Because if something happens at night, and you request recording copy of the footage, they don't have it (Interview with A., president of the Residents Association of Riviera da Barra, October 17, 2014).

Respondents mention, for example, the inability of operators to pay attention to a large number of images simultaneously, while at the same time the perception is that during the night the attention given to the monitoring of the cameras is smaller, which we actually verified. The last excerpt makes it evident that the articulation of the CCTV system with the police did not exist, which is essentially correct, although there would be technical means for such joint work to happen.

In spite of that, what is most important in "These cameras do not work!", which was repeated in the respondents' speech, was the desire hidden behind the expression: I wish these cameras worked. Not only did it mean "working" per se, to stop the crimes, as we have seen, but mainly the desire of control over the monitored spaces. The following

${ }^{27}$ Integrated Operational Center for Social Defense. 
interview excerpts demonstrate how respondents associate this "not working" with crime in general and with small crimes in particular, such as drug use.

The camera is not worth anything, we are often robbed here. There's a handful of these guys in the square doing and dealing drugs. One of these days they set a trash can on fire in front of the pizzeria and the camera didn't catch anything. It should catch those things, so I think it's not working. (Interview with V., merchant and resident in the vicinity of Riviera da Barra Square. November 11, 2014).

I doubt this camera works, there is a lot of trafficking and drug use here in the square and the police never approach them. If this camera worked, we wouldn't have these things happening, would we? If it works, people over there may not even analyze the footage [...] When the loudspeaker announces the camera, the residents, especially the children, even make jokes, 'it's all a lie, that doesn't work', which is of no use (Interview with V., employee of a newsstand on Riviera da Barra Square, October 13, 2014).

Because there are vandals here who destroy the square; some young people do drugs here at night and nothing ever happens. If the camera was working, these things wouldn't happen (Interview with J., passerby in the square of Riviera da Barra, October 19, 2014).

The above excerpts were taken from interviews conducted in the neighborhood of Riviera da Barra, a typical suburban neighborhood of a Brazilian city, where the use of "lighter" drugs, such as marijuana, is relatively common. The drug dealing mentioned in the passages above should be read with caution, since it is usually only the sharing of drugs between friends or trading small amounts of marijuana. Heavy drug trafficking, of course, happens sneakily. The fact that respondents mention the drug dealing activities is only a way to exaggerate the presence and use of drugs in the place.

Brazilian drug legislation ${ }^{28}$ is ambiguous about users. The use of drugs constitutes a crime, but the possible penalties are not strict: the offender may be issued a warning on the effects of the drug, be subject to community services, and also be subject to an educational measure of having to attend an educational program or course. As the police generally turn a blind eye to drug use, since it would be virtually impossible to control ordinary users, the management of the CCTV system also has operators turn a blind eye to drug users, who can be captured easily by the cameras.

Although the use of drugs happens in the square of Riviera da Barra, it is much less frequent than the interviews suggest. The research found that it takes place mostly at night and on weekends. In fact, what is at stake is the presence of groups of young black people in the square, usually from other neighborhoods, and the so-called inappropriate use they make of the square, symbolized by the use of drugs. The respondents' reference to drugs should be read from a moral point of view. Thus, the association made by the interviewees between crimes, drugs and camera indicates that the reference to crimes serves only as a trigger for what should be the effect of the use of cameras in public spaces: to solve

28 "Law no. 11343, as of August 23 2006", accessed on October 18, 2018, http://www.planalto.gov.br/ccivil 03/ ato2004-2006/2006/Lei/L11343.htm. 
all that was considered a problem for an alleged socio-spatial order. The simple presence of cameras in public spaces constantly refers to the never-ending search for the homogenization of spaces, and everything that poses a threat to this goal must be, even if symbolically, eliminated. The interview excerpts below illustrate this desire for order beyond fighting crime and drug users:

Look, I know there's this camera in there, but I'm pretty sure it's not working. I've already been robbed four times here after they installed this camera, there are frequent shootings at the beach, including one that killed a woman. There was this time a woman got beat up by a guy and had a miscarriage on the beach, there are guys who do drugs by the beach rocks and hide guns, there are people who hide guns in the sand too. There was a vacant lot here on the side where people would use to sleep, do drugs, have sex. This problem was only solved when this man who works in the public ministry notified the owner (Interview with J., newsstand owner in Praia da Costa, October 16, 2014).

It seems to me these cameras work for one day and are down for other ten days. They play those sound warnings just sometimes. If it's supposed to be under cover, then it'd be better not to have a camera, they've got to play those warnings to discourage the outlaws. The beach is full of beggars, they drink cachaça ${ }^{29}$, people doing drugs, dogs on the beach, people skateboarding and biking along the boardwalk. I have never seen something being done around here as a result of camera surveillance. Since the time I've been coming to the beach, I haven't noticed any effect because of the cameras. At least here in Praia da Costa, I think it's not working (Interview with J., resident of Praia da Costa, December 11, 2014).

I honestly think this camera doesn't work. At first when they installed it, they discouraged one of these groups of bad guys on the beach, but now it's the same again, it's a total lack of credibility. Even criminals know the cameras are not working. I also think it's unfair that people put up stalls on the boardwalk without having the permission to do so because it's more competition against us, we the ones who have all the paperwork. Hardly ever do they come over to inspect us. The city hall is a like a mother, they only come to check the permits when people who are documented like us complain to them. And when you have an inspection, the officers feel bad for the illegal ones or they take bribes and that's that (Interview with B .. street vendor from Praia da Costa, October 20, 2014).

The excerpts above were taken from interviews conducted at Praia da Costa, a middleclass neighborhood in the city of Vila Velha. Since it is a neighborhood located by the coast, it is attended by people coming from other parts of the city, especially on weekends, when there is a large flow of people heading to the beach. The desire to establish order in a middle-class neighborhood is even more noticeable when the respondents first mention the crimes and then point out what they consider to be problems in the use of public spaces: fights, sexual intercourse, drug users, subjects under the influence of alcohol, the homeless, undocumented street vendors, inappropriate use of sidewalks, etc.

${ }^{29}$ Brazilian liquor distilled from fermented sugarcane juice. 
Finally, there are also references to the uses considered inappropriate of public spaces, as illustrated in the sections below.

My wife is getting rid of her bike this week because that bike lane has become a racetrack, no one goes there for a peaceful ride anymore. Not to mention the skates and scooters. I think the camera should announce these things, 'look, slow down' (Interview with E., resident of Praia da Costa, November 18, 2014).

Here the skaters pull off the benches to use them as a ramp, the children break the coconut trees, people litter. If the camera was working, these things wouldn't happen, I think it should announce right away: "do not litter", "do not break the bench" because it would discourage people to do these things; they would think "look, I'm being watched, they can see it". It would create a general feeling that it works. (Interview with L., newsstand owner at the Riviera da Barra square, October 23, 2014).

According to the excerpts from interviews cited above, the cameras should therefore go beyond the crimes and control of the undesirable subjects. Cameras should act as instruments of spatial ordering: each thing belonging to its proper place: bicycles, skates, scooters and skateboards. In this case, it is not a judgment of value, of course. We do not mean to suggest that certain uses of public spaces should not be respected or that there should be no rules. Our objective is only to highlight how the presence of cameras in public spaces constantly arouses a desire for a mythical order of spaces that oftentimes serves as a potential project of exclusion, mainly for the most deprived social groups.

\section{"THESE CAMERAS DO NOT WORK!": THE UPDATING OF THE PANOPTICON}

In the previous section, we have attempted to point out the main conclusion reached with the research conducted in public spaces in the city of Vila Velha monitored by cameras places where the interviewees claim cameras do not work. For the respondents, the cameras do not work primarily because they are not able to meet the demand of public security of the city, which justified the implementation of the CCTV system. The presence of cameras does not inhibit the criminals, and they are they incapable of recording the crimes. That is, crimes continue to occur and there is a presumed perception that nothing has changed since the implementation of the system.

However, it was observed that the "not working" assumption goes beyond the action of cameras before crimes. Respondents clearly wished the cameras to work as instruments of control. References to the crimes would always be overlapped by the annoyance caused by the presence of people or due to the use of the public spaces considered undesirable for a utopian project of order. The cameras would symbolize the everlasting memory of a public space characterized by homogeneity.

Let us now turn to the panopticon, or rather, to the interpretation of the panopticon by Foucault, panopticism. ${ }^{30}$ From a non-literal point of view, panopticism is nothing more than a moral instrument of normalization, a project of absolute enlightenment to capture

30 Discipline and Punish, 195. 
all dark spots, especially the ones of individuals and of society as a whole, which are not in the scope of a pre-stablished rule. This is not to say that this will necessarily happen, because panopticism is an ideal, although concrete social effects can be observed.

In the case of the public spaces where we have been to, the dark spots are precisely what disturbs the intended social order, that is, the uses and people considered undesirable for those places. The cameras are there to constantly update what is "right" and what is "wrong", to separate the "good" and the "bad" individuals. They end up fostering a state of permanent control that leads to the non-acceptance of the differences that are, essentially, what characterize the existence of public spaces. ${ }^{31}$ According to Angelo Serpa, it is not only a strictly physical acceptance, but also a symbolic one, because:

if it is true that the adjective "public" refers to a generalized and unrestricted accessibility, a space accessible to all must mean, on the other hand, something more than an ordinary physical access to "open" spaces of collective use. ${ }^{32}$

A space accessible to all must therefore mean more than the presence of plurality, but also its acceptance and legitimacy.

Public spaces are the physical dimension which provide a ground for citizenship. Ideally speaking, in these spaces a formal legal framework should guarantee complete isonomy and, therefore, support the expression of the individualities of the citizens in a necessarily plural universe. But legal norms to protect public spaces are not enough to guarantee isonomy. Caldeira demystifies the idealization of public spaces affected by unequal relations of class, ethnicity and gender ${ }^{33}$. Foucault recognizes how formal and legal liberties cloud the disciplines as essentially unequal and asymmetric mechanisms. ${ }^{34}$

The present empirical research carried out in the public places in the city of Vila Velha shows that isonomy, under a sovereign legal framework, should be deemed relative. It also shows that a CCTV system can be part of such small and unequal surveillance mechanisms addressed by Foucault. ${ }^{35}$ Representing symbolic walls of exclusion, it is possible to conclude that the use of the CCTV system weakens the public spaces of the city of Vila Velha.

There is yet another possible association of our research with panopticism. The exercise of power radiated by the social body is only possible because it dissociates itself from a radiating center and begins to function in the form of a network. As it has been previously addressed, panopticism is not a force entirely given to one who would exercise it over

\footnotetext{
${ }^{31}$ We agree with Roy Coleman, "Reclaiming the Streets: Closed Circuit Television, Neoliberalism and the Mystification of Social Divisions in Liverpool, UK", Surveillance and Society 2:2/3 (2004), 394, when the author reinforces the care that must be taken with the mythification of public spaces considering the period prior to neoliberalism in the United Kingdom, and also that the celebration of difference is often part of the neoliberal strategy to mask inequalities. "Debates concerning the right to access, use and define the city need to take on material issues through which inequality is brought into focus as something to be challenged (not celebrated) or seen as merely 'different'" (COLEMAN, 2004, p. 304).

${ }^{32}$ Angelo Serpa. O espaço público na cidade contemporânea (2007), 16.

${ }^{33}$ Teresa Pires do Rio Caldeira. City of walls: Crime, Segregation and Citizenship in Sao Paulo (2001), 299-300.

${ }^{34}$ Discipline and Punish, 222.

${ }^{35}$ Ibid.
} 
others. The panopticon is a machine that envelops everyone; an undesignated power in which "each person, depending on his place, is watched by all or certain of the others. You have an apparatus of total and circulating mistrust, because there is no absolute point" ${ }^{36}$ Thus, in the case of the Vila Velha CCTV system, one should not understand the use of cameras only as a power whose source is the state, which has decided to implement the system. The police rarely act directly in public spaces through footage produced by the cameras, and the city hall has no interest in using them to tackle other problems of urban administration ${ }^{37}$, either by disinterest or by the limits of surveillance that we presented before. The most important point here is to understand the system as a network of control that, by multiplying the surveillance through an electronic approach, ends up promoting the multiplicity of crossed eyes between citizens. Each citizen becomes the gear in a system that starts to work automatically.

We also need to emphasize that there is no "justice" because there is a certain hierarchy in this surveillance. If the cameras are disseminated by the state as instruments to fight crime, and if crime in Brazil is associated with certain marginalized social groups, especially the poor and black individuals, then control is preferentially directed onto such groups when they pass by such public spaces. In the case of Brazil, such groups are treated as internal enemies of the Brazilian state, The Others, who are no longer the guerrillas or communists persecuted during the military regime through which Brazil underwent between 1964-1984, but the "criminals", the "outlaws" or the homeless, considered as characters who contaminate, pollute and break social rules. They are constant targets of repression, stigma and prejudice in their own living spaces, but also where they circulate, as the long record of abuse by the Brazilian military police ${ }^{38}$ (that kills the most in the world) confirms when the poor and black population are taken into account, and also homicides in Brazil that particularly affect poor and black young men, as shown by Zanotelli et al. ${ }^{39}$

As it can be seen, if only the great economic and social inequalities that make Brazil a country affected by the segregation of certain social groups would not suffice, injustices are also part of the institutions, such as it is for the police. ${ }^{40}$ And what is more impressive, the institutional violence in Brazil has the support of significant parts of the population. As if that were not enough, Brazil has one of the highest homicide rates in the world; daily violence is part of Brazilian society: violence is institutional and social; public lynching perpetrated by the population is relatively frequent. ${ }^{41}$ The use of the CCTV system in the city of Vila Velha demonstrates how directing control at certain social targets is irradiated

\footnotetext{
36 Foucault, "The eye of power,"158.

${ }^{37}$ Bricalli, "O paradoxo da cidade monitorada", 96.

${ }^{38}$ Brazilian police are divided between a civilian (in charge of judicial and administrative tasks) and a military force (in charge of patrolling the streets). The military training received by the police in charge of dealing with citizens in public spaces, particularly after the military dictatorship in Brazil (1964-1985), employs the same repressive tactics used against political opponents to the repression of crime, "the internal enemy".

${ }^{39}$ Cláudio Luiz Zanotelli et al, Atlas da criminalidade no Espírito Santo (2011), 113.

40 Teresa Pires do Rio Caldeira, City of Walls, 138.

${ }^{41}$ Ibid., 207.
} 
by Brazilian society when citizens themselves instill prejudice by clearly exposing what the role of the cameras should be, that is, the control over marginalized social groups.

\section{CONCLUSIONS}

In this paper, we have attempted to problematize the use of the panopticon as a theoretical reference in the studies of CCTV systems. Since the CCTV systems produce paradoxical surveilling effects over the spaces, the panopticon should be used with the due exceptions.

Empirical research in various contexts shows that the surveillance performed by cameras can and should be relativized. In general, for instance, people in public spaces are not aware they are being watched or deal indifferently with surveillance. On the other hand, ethnographic research conducted in the control rooms where the cameras are operated demystify the technological determinism and present the limits of the functioning of a system by taking into account the importance of the human labor "behind" the cameras. In this case, the state's and its agents' correctional effects upon surveilled spaces and individuals who are passing by are virtually nonexistent.

Alternatively, we believe that the relativization of control can lead to pitfalls in the interpretation of the operation of CCTV systems. Drawing on what Michel Foucault calls panopticism, a critical reading that makes the panopticon a machine whose social effects go beyond the limited social institutions and become a general trend in society as a whole, we propose a non-literal reading of the panopticon, seeking to understand it as a metaphor for the surveillance that is exerted by the multiplication of intertwined views which indicate the exercise of power as a network.

Through the present research conducted in the public spaces of a Brazilian city, we can conclude that it is not possible to draw a univocal conclusion regarding the system and the effects of surveillance. If on the one hand direct control over the space is minimal and people generally live as if the cameras did not exist, on the other hand it was found that the presence of the cameras promotes a state of control over the citizens and their spaces. The typical phrase of the respondents was that "the cameras don't work!". But what does this mean? It means, first of all, that the system has no credibility with the population, since the general belief is that the cameras do not meet the city's demand for public security, that is, crimes keep on happening and are not recorded by the cameras. In contrast, the interviews indicate that linking cameras to crimes would fulfil the interviewees' desire that cameras would serve as instruments of social control. From the interviewees' point of view, the cameras had to "work" not only as tools to fight crime, but also, and mainly, as a way of controlling undesirable social groups, such as the poor, black people, the homeless, drug users, subjects under the influence of alcohol, and undocumented vendors. The mere presence of the cameras in public spaces and the memory of their existence updated the modern project of order and homogenization of spaces. Whatever hindered this project of order, all persons or uses considered inadequate should be, even if only symbolically, eliminated. The CCTV system updated what the panopticon essentially is: a moral instrument of normalization. 


\section{References}

Beck, Ulrich, Risk society: towards a new modernity. London: Sage, 1992.

Bauman, Zygmunt and David Lyon, Liquid Surveillance. Cambridge: Polity, 2013.

Bentham, Jeremy, "Panopticon or the Inspection-House" [1791], in The Panopticon writings, ed. Miran Bozovic, 29-95. London: Verso, 1995.

Bricalli, Iafet Leonardi, “O paradoxo da cidade monitorada: vigilância limitada e espaços públicos fragilizados a partir do estudo do Sistema de cameras do município de Vila VelhaES", Master diss., Federal University of Espírito Santo, 2015.

Bricalli, Iafet Leonardi, and Zanotelli, Cláudio Luiz, "A fragilização dos espaços públicos a partir da utilização de cameras de vigilância na cidade de Vila Velha (ES)," Revista Geo UERJ, no. 29 (July 2016): 133-169. https://doi.org/10.12957/geouerj.2016.16928

Caldeira, Teresa Pires do Rio, City of walls: Crime, Segregation and Citizenship in Sao Paulo. California: University of California Press, 2001.

Coleman, Roy, "Reclaiming the Streets: Closed Circuit Television, Neoliberalism and the Mystification of Social Divisions in Liverpool, UK" Surveillance and Society 2:2/3 (2004), 293-309. https://doi.org/10.24908/ss.v2i2/3.3379

Coleman, Roy, and Sim, Joe, "'You'll never walk alone': CCTV surveillance, order and neoliberal rule in Liverpool city centre", British Journal of Sociology 51:4 (2002), 623-639.

\section{https://doi.org/10.1080/00071310020015299}

Deleuze, Gilles, Foucault [1986]. Minneapolis: University of Minnesota Press, 2006.

Deleuze, Gilles, “Postscript on control Societies" [1990], in Negotiations, 177-82. New York: Columbia University Press, 1995.

Firmino, Rodrigo José, Trevisan, Elisa, "Eyes of Glass: Watching the watchers in the monitoring public spaces in Curitiba, Brazil," Surveillance and Society 1:10 (2012), 28-41.

https://doi.org/10.24908/ss.v10i1.4218

Foucault, Michel, Discipline and Punish: the birth of the prison [1975]. New York: Pantheon Books, 1977.

Foucault, Michel, "The eye of power" [1977], in Power/Knowledge: Selected Interviews and Other Writings 1972-1977, ed. Colin Gordon, 146-165. New York: Pantheon Books, 1980.

Foucault, Michel, Society Must Be Defended: Lectures at the Collège de France (1975-76). New York: Picador, 2003.

Foucault, Michel, Security, Population, Territory. Lectures at the Collège de France 1977-1978. New York: Picador, 2009.

Garland, David, The Culture of Control: crime and social order in contemporary society. Oxford: OUP, 2001.

Koskella, Hille, "'The gaze without eyes': video-surveillance and the changing nature of urban space," Progress in Human Geography 24:2 (2000), 243-265.

https://doi.org/10.1191\%2F030913200668791096

Mucchielli, Laurent, Vous êtes Filmés: enquete sur le bluff de la vidéosurveillance, Malakoff: Armand Colin, 2018. 
Menichelli, Francesca, “WHAT'S CRIME GOT TO DO WITH IT? CCTV, urban security and governing elites," PhD diss., Università degli studi Milano Bicocca, 2012.

Norris, Clive, and Armstrong, Gary, The Maximum Surveillance Society: The Rise of CCTV. Oxford: Berg, 1999.

Serpa, Angelo, O espaço público na cidade contemporânea. São Paulo: Contexto, 2007.

Smith, Gavin. J. D., "Behind the Screens: Examining Constructions of Deviance and Informal Practices among CCTV Control Room Operators in the UK", Surveillance \& Society 2:2/3 (2004), 376-395. https://doi.org/10.24908/ss.v2i2/3.3384

Zanotelli, Cláudio Luiz et al, Atlas da criminalidade no Espírito Santo. São Paulo: Annablume, Fapes. 2011.

Author info

Iafet Leonardi Bricalli

PhD Candidate

University of Genoa

iafet.leonardibricalli@edu.unige.it

I have a degree and a Masters in Geography from the Federal University of Espírito Santo, located in the southeast of Brazil. During my academic formation, I have always been interested in the field of Urban Geography research, particularly in the areas of urban segregation and socio-spatial control. I am currently a PhD candidate in Social Sciences at the University of Genoa (Italy). 